\title{
Recycling of Spent Reverse Osmosis Membranes for Second Use in the Clarification of Wet-Process Phosphoric Acid
}

\author{
Khaoula Khaless ${ }^{1, *}$, Brahim Achiou ${ }^{1}$ (D), Rachid Boulif ${ }^{1}$ and Rachid Benhida ${ }^{1,2, *}$ \\ 1 Department of Chemical and Biochemical Sciences, Green Process Engineering (CBS.GPE), Mohammed VI \\ Polytechnic University, 43150 Ben Guerir, Morocco; brahim.achiou@um6p.ma (B.A.); \\ rachid.boulif@um6p.ma (R.B.) \\ 2 Institut de Chimie de Nice, UMR7272, Université Côte d'Azur, F06108 Nice, France \\ * Correspondence: khaoula.khaless@um6p.ma (K.K.); rachid.benhida@um6p.ma (R.B.)
}

check for updates

Citation: Khaless, K.; Achiou, B.; Boulif, R.; Benhida, R. Recycling of Spent Reverse Osmosis Membranes for Second Use in the Clarification of Wet-Process Phosphoric Acid. Minerals 2021, 11, 637. https:// doi.org/10.3390/min11060637

Academic Editors: Mostafa

Benzaazoua, Yassine Taha and Abdellatif Elghali

Received: 5 March 2021

Accepted: 29 April 2021

Published: 16 June 2021

Publisher's Note: MDPI stays neutral with regard to jurisdictional claims in published maps and institutional affiliations.

Copyright: (c) 2021 by the authors. Licensee MDPI, Basel, Switzerland. This article is an open access article distributed under the terms and conditions of the Creative Commons Attribution (CC BY) license (https:/ / creativecommons.org/licenses/by/ $4.0 /)$.

\begin{abstract}
Various techniques have been used to "clean-up" wet-process phosphoric acid such as precipitation, flotation and adsorption. To address the potential of membrane processes in the phosphoric acid clarification process, this study explores the benefits of membrane techniques as a green separation technique for phosphoric acid clarification in an eco-efficient way through the use of recycling spent reverse osmosis membrane. Regenerated membrane was used to study the phosphoric acid clarification at a laboratory scale. They were immersed in an oxidizer for at most seven days. The samples were characterized systematically before immersion in an oxidant media. In this study, the potential to regenerate spent membranes and application of this media to clarify the $29 \% \mathrm{P}_{2} \mathrm{O}_{5}$ phosphoric acid was demonstrated. This study shows, through experiments, that the reverse osmosis (RO) membranes could achieve a rejection of $70 \%$ and $61 \%$ for suspended solid and organic matter, respectively. These promising results will pave the way for implementation of these membranes in phosphoric acid treatment. Moreover, besides being economically advantageous, the use of the spent membrane is likely an environmentally friendly route (no waste, no organic solvent and effluent to be regenerated later on).
\end{abstract}

Keywords: membrane; chemical regeneration; phosphoric acid; clarification

\section{Introduction}

Desalination of seawater using reverse osmosis (RO) is widely considered to be the most efficient and profitable way not only to produce of fresh water for populations but also to treat water for industrial uses [1]. The large amount of solid waste generated from $\mathrm{RO}$ plants in terms of spent membranes should be correctly managed. As reported by Landaburu-Aguirre et al., globally, more than 840,000 end-of-life membranes are disposed, which is equivalent to more than 14,000 tons per year [2]. In most of cases, the spent membranes are commonly disposed to landfill in the classical waste management approach [3]. Nowadays, sustainable management of end-of-life membranes is a challenge for desalination industries. Chemical oxidative treatment (or chemical conversion) is one of most common and feasible spent RO membrane recycling approaches and has been adopted by several researchers [3-5]. Coutinho de Paula et al. evaluated an environmental and economic evaluation of the benefits of recycling end-of-life $\mathrm{RO}$ membranes based on chemical oxidation of an aromatic polyamide-based active layer using sodium hypochlorite $(\mathrm{NaClO}, 10-12 \%)$ [3]. They showed that the recycled membrane has the features and performance of an ultrafiltration (UF) membrane. García-Pacheco et al. treated spent RO membranes chemically using concentrated solutions of free chlorine to convert to nanofiltration membranes [6]. The recycled membrane was used for treating natural brackish water at the pilot scale and it is shown that the nanofiltration membrane has kept their performances during the four months of filtration. 
Fouling is generally caused by the accumulation of suspended materials originating from organic, inorganic, biological and colloidal species on the membrane [7]. These substances contribute to the physical, chemical or biological degradation of the active layer affecting the performance of the membrane in terms of permeability and selectivity [8].

Wet-process phosphoric acid (WPPA) is produced from the acidic attack of phosphate rock [9], which is an important intermediate in the manufacturing of fertilizers and the production of purified acids for the food industry, pharmaceutical products and surface treatments [10]. Various treatments have been used to clarify WPPA such as coagulation flocculation, decantation, adsorption and membrane filtration [11]. Coagulation/flocculation is the most economical technique for removal of suspended solids from liquid. However, this technique does not eliminate organic matter and produces a large amount of sludge that requires further processing. The membrane processes especially microfiltration and ultrafiltration are emerging separation techniques to remove particles based on their size [12]. Generally, WPPA contains a variety of impurities including suspended solids, soluble compounds as well as organic matter originating mainly from rock phosphate [13]. Clarification is an important step in the purification process of phosphoric acid not only to increase the purity of produced acid, but also to avoid some technical problems in industrial installations. A study by Graza et al. reported the possibility of removing $\mathrm{Pb}^{2+}$ in an acid medium composed of phosphoric acid and perchloric acid by ultrafiltration using sodium dodecyl sulphate (SDS) as a surfactant [14]. In optimal conditions of pressure and SDS concentration, the retention rate obtained was $99 \%$, which generated a concentration of $0.24 \mathrm{ppm}$ instead of $20.72 \mathrm{ppm}$. The present study aims at finding a membrane that is resistant to aggressive media and capable of clarifying phosphoric acid. The membranes types used are Minitan-S PTGC OMS10 (Millipore), polysulfone (propylene support) and have a cut-off of 10,000 Daltons [15]. New Logic American Company has developed a filtration system for phosphorus compounds using a Vibratory Shear Enhanced Process (VSEP) that involves a microfiltration membrane module with a specific construction for hightemperature use. The use of vibrating polymer membranes has an advantage over the use of filter presses and other conventional methods of clarification. Patent WO2013133684A1 relates to a process developed for the purification of phosphoric acid by nanofiltration. This process requires a clarification step by the coagulation/flocculation in the upstream of the nanofiltration process in order to avoid problems related to scaling and clogging of the nanofiltration membrane besides enhancing the quality of produced phosphoric acid. Regardless of the scope of application, membranes must frequently undergo cleaning and/or disinfection procedures in order to eliminate the clogging, which results from the filtration. This cleaning is responsible for accelerating the aging of membrane materials, which directly affects the technical and economic performance of membrane processes. The sustainability of the latter depends on the identification of the main factors responsible for aging and the understanding of the mechanisms that govern it. Therefore, it is possible to recycle spent RO membranes for use as ultrafiltration or microfiltration membranes by removal of the active layer using a strong stripping agent. It is highly likely that these membranes are capable of filtering solids and macro-impurities that are present in WPPA. In this study, a process is reported that allows for the recycling of spent membranes taken from seawater desalination plants or similar plants and their reuse them as microfiltration or ultrafiltration membranes. The recycling is based on the removal of both the fouling and active layers of spent membrane using a suitable stripper to avoid damaging the microporous layer of the membrane [16]. The regenerated membrane was subjected to clarification of a WPPA to access its performance in terms of flux and rejection of suspended particles and organic matter.

The goal of this work is to assess the chemical treatment of spent RO membranes discarded from an industrial seawater desalination plant. Four strong strippers, namely $\mathrm{KMnO}_{4}, \mathrm{NaOH}, \mathrm{H}_{2} \mathrm{O}_{2}$ and TBP, were investigated to chemically remove both the active and fouling layers of the spent membrane. The converted membrane was applied to a clarification of WPPA. 


\section{Materials and Methods}

\subsection{Chemicals}

In this study, several end-of life RO membranes, which were discarded after nine years of service from the seawater desalination plant of the OCP group, were located in Lâayoune, in the south of Morocco. The used RO membrane is an energy-saving polyamide (ESPA) with an 8" spiral wound module manufactured by Hydranautics, Oceanside, CA, USA. Flat-sheet membrane pieces of $0.15 \mathrm{~m}^{2}$ were taken out from spent ESPA RO membranes.

WPPA ( $29 \mathrm{wt} . \%$ of $\mathrm{P}_{2} \mathrm{O}_{5}$ ) was produced via the dihydrate process of the OCP group Jorf Lasfar, El Jadida, Morocco. Sodium bisulfate $\left(\mathrm{NaHSO}_{3}, 93 \mathrm{wt} . \%\right)$, hydrogen peroxide $\left(\mathrm{H}_{2} \mathrm{O}_{2}, 33 \mathrm{wt} . \%\right)$, potassium permanganate $\left(\mathrm{KMnO}_{4}, 99.4 \mathrm{wt} . \%\right)$, tributyl phosphate (TBP) $\left(\mathrm{C}_{12} \mathrm{H}_{27} \mathrm{O}_{4} \mathrm{P},>97\right.$ wt. $\left.\%\right)$ and sodium hydroxide $(\mathrm{NaOH}, 98$ wt.\%) were purchased from Solvachim and SNEP Companies, Casablanca City, Morocco. Distilled water was used for the preparation of solutions and filtration experiments.

\subsection{Stripping of Spent Membrane}

In this study, both the fouling and active layers of spent ESPA RO membrane were chemically removed using four strong strippers notably $\mathrm{KMnO}_{4}, \mathrm{NaOH}, \mathrm{H}_{2} \mathrm{O}_{2}$ and TBP. Initially, the spent membrane was cleaned with water, followed by cleaning using sodium bisulfate solution $(0.2 \mathrm{~g} / \mathrm{L})$. Thereafter, the membrane was completely soaked in stripping solution for between 1 and 7 days. Finally, the stripping solution was neutralized by using sodium bisulfate solution. The obtained membrane was rinsed several times with water and then it was kept in water until the use for characterization or filtration.

\subsection{Filtration of Wet Process Phosphoric Acid}

Microfiltration experiments were conducted on a dead-end stainless steel stirred cell with effective filtration area of $43 \mathrm{~cm}^{2}$ and feed volume of $1 \mathrm{~L}$. The cell was placed on an anti-vibration table and connected with compressed nitrogen gas to control transmembrane pressure (TMP) by means of a needle-point valve. All filtration experiments were carried out in an air-conditioned room at $25^{\circ} \mathrm{C}$. The volume of permeate was continuously measured at different TMPs during a filtration time of $2 \mathrm{~h}$. The permeate flux $\mathrm{J}_{\mathrm{v}}$ $\left(\mathrm{L} \mathrm{h}^{-1} \mathrm{~m}^{-2}\right)$ and permeability $\mathrm{L}_{\mathrm{p}}\left(\mathrm{L} \mathrm{h}^{-1} \mathrm{~m}^{-2} \mathrm{bar}^{-1}\right)$ and hydraulic resistance of the membrane $R_{\mathrm{m}}\left(0.0235 \mathrm{~m}^{-1}\right)$ of the membrane were calculated according to Equations (1)-(3), respectively [17].

$$
\begin{aligned}
\mathrm{J}_{\mathrm{v}} & =\frac{\mathrm{V}}{\mathrm{A} \times \mathrm{t}} \\
\mathrm{L}_{\mathrm{p}} & =\frac{\mathrm{J}_{\mathrm{v}}}{\mathrm{TMP}} \\
\mathrm{R}_{\mathrm{m}} & =\frac{1}{\mu \times \mathrm{L}_{\mathrm{p}}}
\end{aligned}
$$

where $\mathrm{V}(\mathrm{L})$ is the volume of permeate, $\mathrm{A}\left(\mathrm{m}^{2}\right)$ is the effective filtration area, $\mathrm{t}(\mathrm{h})$ is the filtration time, TMP (bar) is the transmembrane pressure and $\mu$ (2.84 Pa s) is the viscosity of the permeate. It is worth noting that the flux and permeability were carried with an accuracy of $\pm 2 \%$.

WPPA with a concentration of $29 \% \mathrm{P}_{2} \mathrm{O}_{5}$ was filtered under a pressure of 4 bar at room temperature. The efficiency of the recycled membrane was evaluated by the measurement of permeate flux and the rejection of suspended materials and organic matter. The rejection $\mathrm{R}(\%)$ is calculated according to Equation (4) [18].

$$
\mathrm{R}=\left(1-\frac{\mathrm{C}_{\mathrm{p}}}{\mathrm{C}_{\mathrm{f}}}\right) \times 100
$$

where $C_{f}$ is the concentration in the feed and $C_{p}$ is the concentration in the permeate. 


\subsection{Instruments and Analyses}

The number of cultivable bacteria per membrane surface was determined according to the incubation method in a rich nutrient agar medium at $22{ }^{\circ} \mathrm{C}$ over of period of $72 \mathrm{~h}$. In this study, an autopsy was proceeded on the active layer (skin + deposition of fouling), the size separation and the deposition of fouling. Full examination of the membrane was performed by chemical and microbiological analysis of the deposit, chemical oxidation tests (Fujiwara Test), and scanning electron microscopy (SEM) equipped with energy dispersive spectroscopy (EDS) (Hitachi, Tokyo, Japan). The suspended solids was determined by the gravimetry method [19], while the organic matter was measured using a Skalar Formacs TOC analyzer (Breda, The Netherlands). It is worth noting that the suspended solids and the organic matter were made with $\pm 1 \%$ accuracy.

\section{Results and Discussion}

\subsection{Autopsy of Spent RO Membrane}

\subsubsection{Visual Inspection}

The external inspection shows that the general aspect of the outer wrap of spent ESPA membrane is in a good condition (Figure 1a). It is worth noting that no cracks and/or any other physical damage were detected, indicating that the spent membranes could likely support the hydraulic pressure during the filtration application. Therefore, this could be considered as a favorable indicator in terms of mechanical strength to reuse spent membranes in ultrafiltration or microfiltration applications after chemical oxidation treatment [20]. The internal examination of spent ESPA membranes reveals the presence of a brown deposit on the outer membrane surface (brine side), while the conductive mesh and the inner surface of membrane (permeate side) are clean (See Figure $1 \mathrm{~b}-\mathrm{d}$ ).
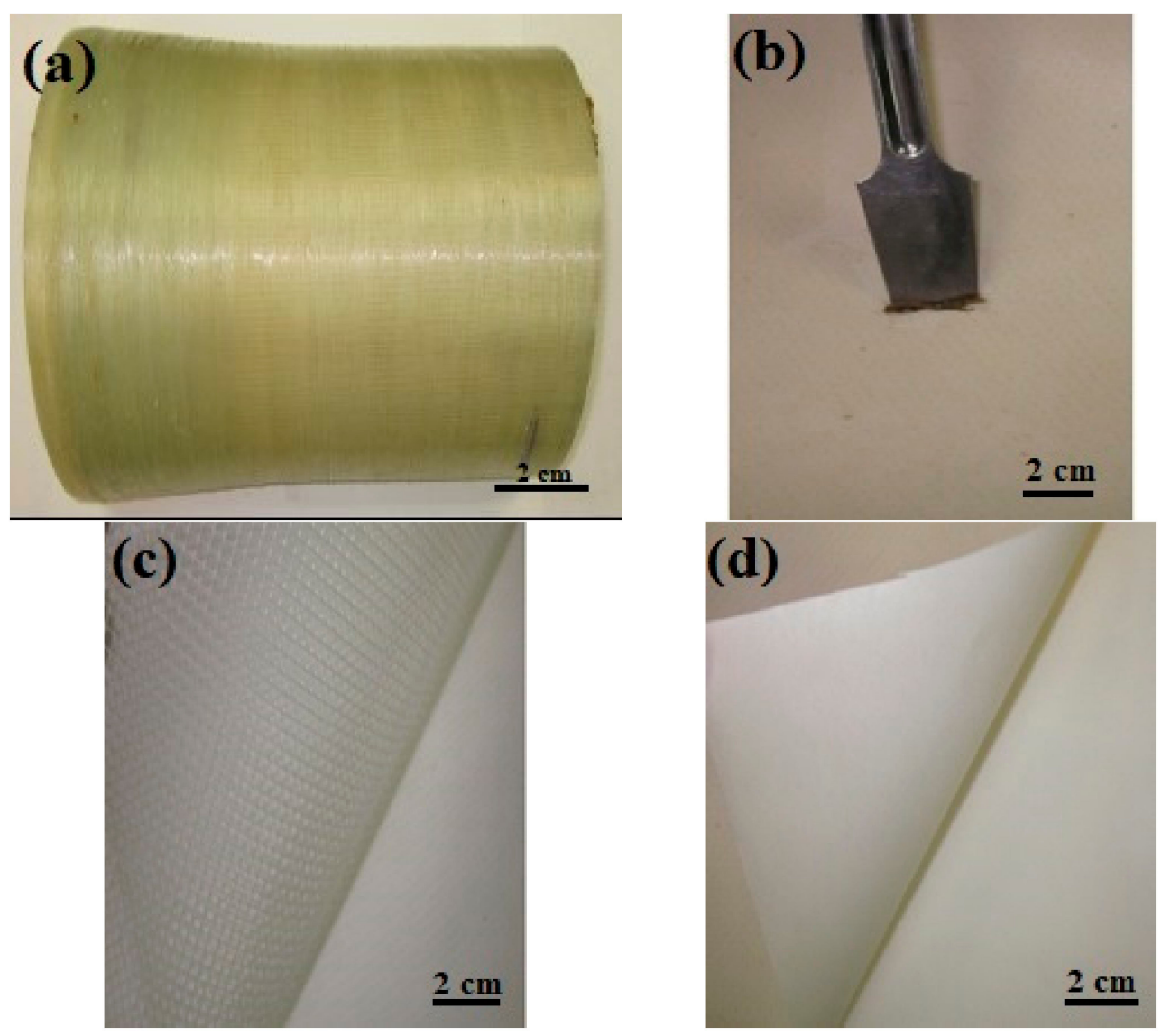

Figure 1. Photos of spent ESPA membrane: (a) external view of the membrane and the internal view including (b) outer surface of membrane, (c) conductive mesh and (d) inner surface of membrane. 


\subsubsection{Chemical Composition}

The deposit collected from the outer surface of the spent membrane was characterized to quantify the moisture and to analyze the organic and inorganic materials. It was found that the deposit contained about $67.90 \%$ of moisture. The chemical composition of dried deposit at $105^{\circ} \mathrm{C}$ with density of $0.12 \mathrm{mg} / \mathrm{cm}^{2}$ is then given in Table 1 . It was revealed that the dry deposit is mainly composed of organic matter (62.33 wt.\%), as quantified by weight loss at $500{ }^{\circ} \mathrm{C}$ [21] and the insoluble fraction in $\mathrm{HCl}$ presenting $31.03 \%$ of the deposit. In addition, the inorganic impurities are about $4 \mathrm{wt} . \%$ including iron oxide and phosphorus pentoxide (Table 1).

Table 1. Composition of the dry deposit collected from the membrane surface.

\begin{tabular}{ccccccccc}
\hline Compound & Organic Matter & Insoluble in $\mathbf{H C l}$ & $\mathrm{Fe}_{2} \mathbf{O}_{3}$ & $\mathbf{P}_{2} \mathbf{O}_{5}$ & $\mathbf{C a O}$ & $\mathbf{M g O}$ & $\mathrm{CO}_{2}$ & Others \\
\hline wt. $\%$ & 62.33 & 31.03 & 3.02 & 0.89 & $<0.10$ & $<0.10$ & $<0.10$ & 2.73 \\
\hline
\end{tabular}

\subsubsection{Microbiological Characterization}

The number of cultivable bacteria per surface area was determined after incubation method in rich nutrient agar medium at $22{ }^{\circ} \mathrm{C}$ during $72 \mathrm{~h}$. Microbiological analysis of the spent membrane revealed the presence of microorganisms in different membrane parts. It was found that the amount of biogrowth in the active membrane layer, feed-rejection mesh and permeate conductive mesh was respectively 192,62 and $10 \mathrm{CFU} / \mathrm{cm}^{2}$. It can be concluded that bacteria were less abundant in the feed-rejection mesh and present in very low numbers in the permeate conductive mesh.

\subsubsection{SEM Examination}

Figure 2 corresponds to a topographical image of spent RO membrane obtained by SEM analysis at low magnification $(50 \times)$. As can be clearly observed, three regions could be distinguished: (i) the black area corresponded to the membrane surface, (ii) the gray area is deposit layer on the surface of the membrane and (iii) the white areas are just particles in the deposit that was present on the membrane. The EDS analysis of three regions is illustrated in Figure 3 and it was carried out to investigate their elementary chemical composition. The sulfur detected in the black area corresponds to polyether sulfone of the active layer of the membrane. The chemical composition of the white area mainly consists of $\mathrm{Al}$ and $\mathrm{Si}$ elements besides the low amount of $\mathrm{Na}$ and $\mathrm{K}$, suggesting the presence of alumino-silicate in the form of clay [22]. The gray area shows the presence of $\mathrm{Si}, \mathrm{Al}, \mathrm{Mg}$, $\mathrm{Ca}$ and $\mathrm{Na}$ elements due to an acculturation of inorganic impurities on membrane surface.
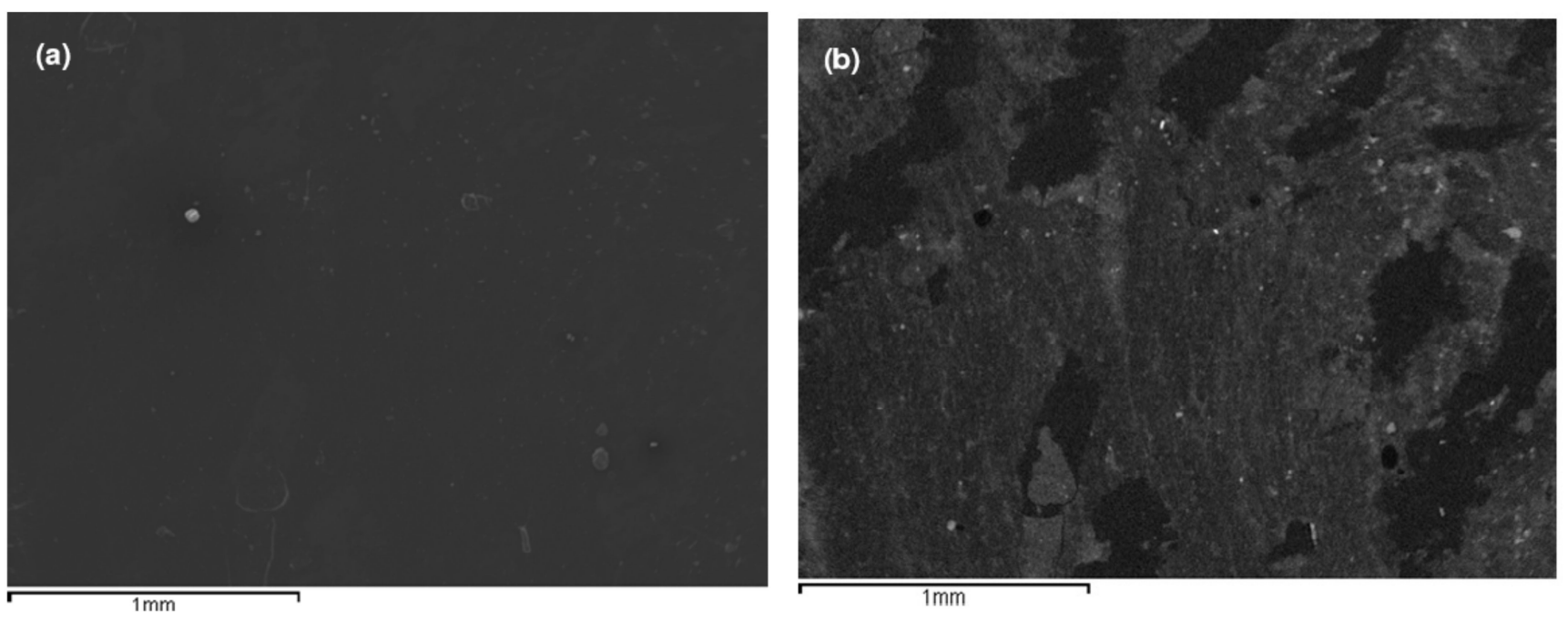

Figure 2. SEM micrographs of spent RO membrane: (a) Topographic image and (b) 'Z-Contrast' image. 


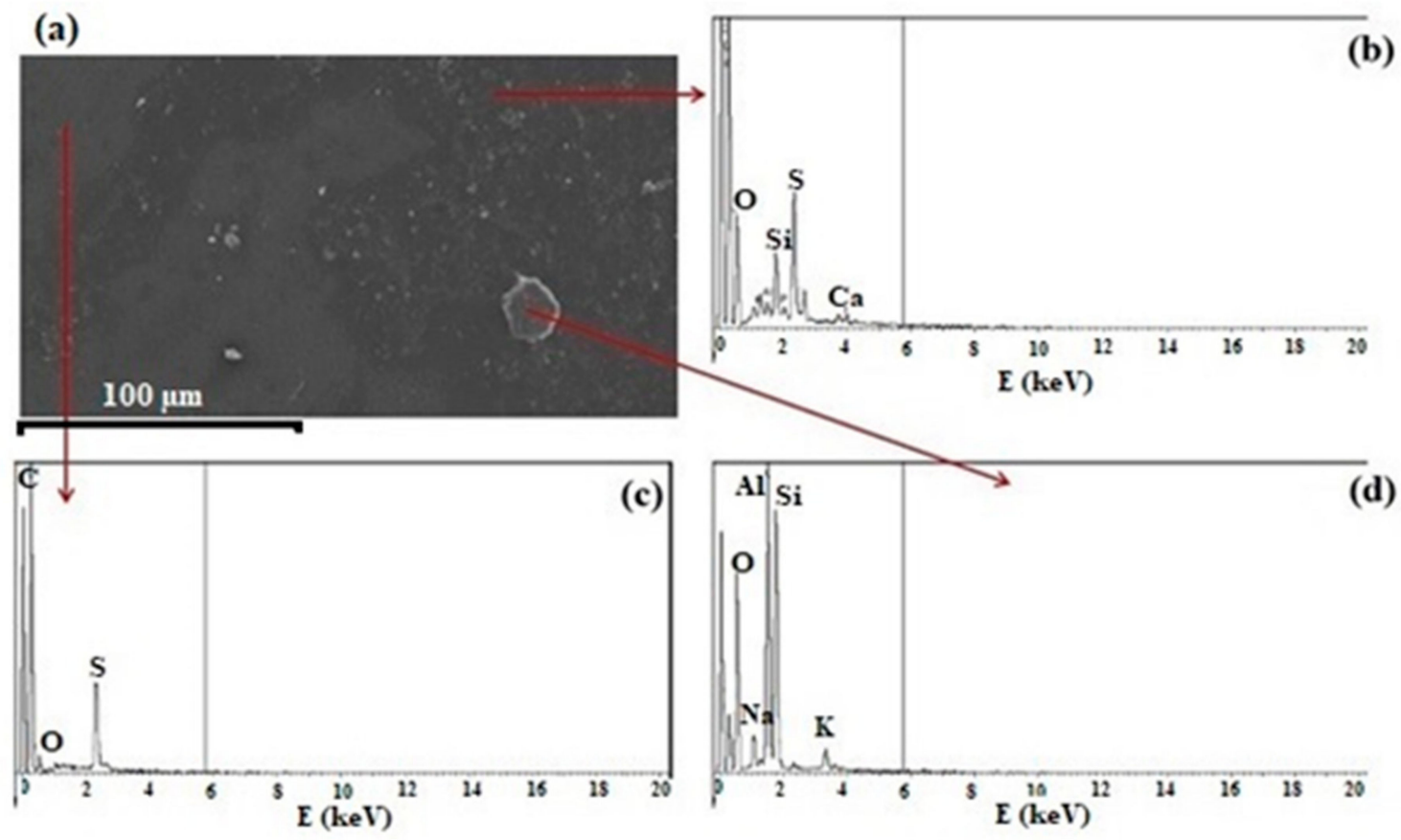

Figure 3. SEM image (a), and EDS spectra of black area (b), white area (c) and gray area (d) of membrane surface.

\subsection{Characterization of Regenerated Spent Membrane}

The preliminary tests allowed for the selection of suitable stripping agents for the degradation of the active layer of spent membrane and these are presented in Table 2. Figure 4 shows the degradation of the active skin of spent $\mathrm{RO}$ membranes treated with $\mathrm{NaOH}$.

Table 2. Preliminary tests for the selection of the stripping agent.

\begin{tabular}{cc}
\hline Strippers & Visual Remarks During First Day \\
\hline $\mathrm{NaOH}$ & Partial degradation of the active layer \\
$\mathrm{KMnO}_{4}$ & Appearance of the blisters + degradation of the active skin \\
$\mathrm{H}_{2} \mathrm{O}_{2}$ & No effect on active skin \\
$\mathrm{TBP}$ & No effect on active skin \\
$\mathrm{NaOH}(50 \%)+\mathrm{H}_{2} \mathrm{O}_{2}(50 \%)$ & No effect on active skin \\
$\mathrm{NaOH}(50 \%)+\mathrm{KMnO}_{4}(50 \%)$ & Partial degradation of the active \\
\hline
\end{tabular}
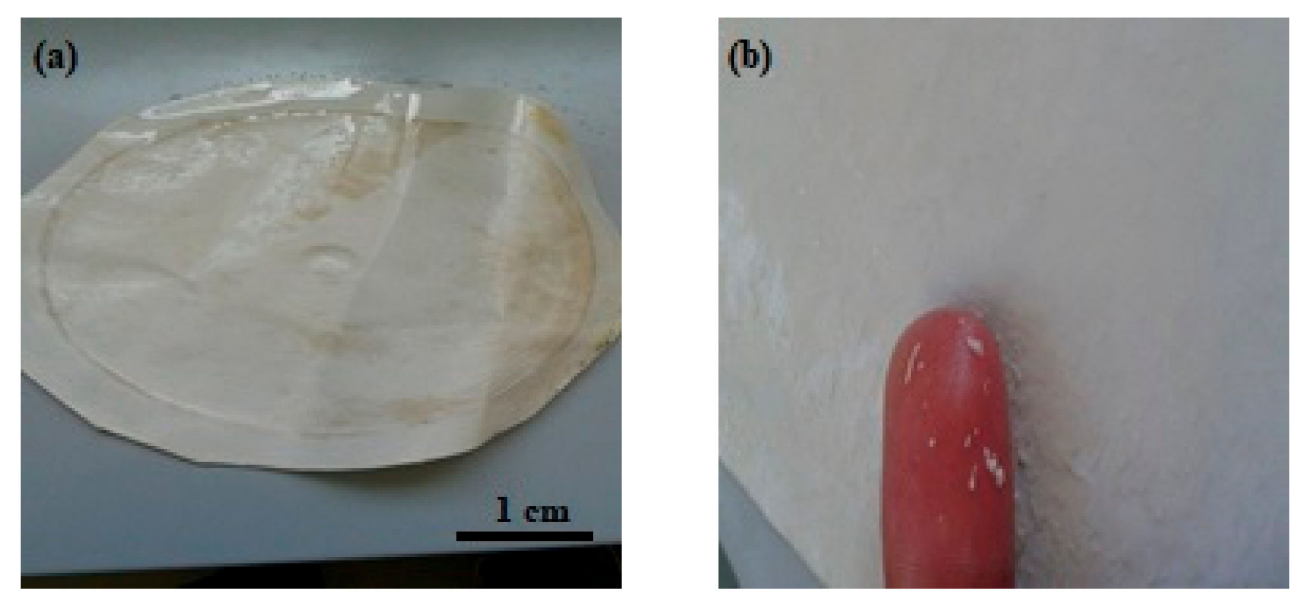

Figure 4. Photos of spent $\mathrm{RO}$ membrane (a) after treatment with $\mathrm{NaOH}$ and (b) degradation of active layer. 


\subsubsection{XRD}

The XRD analysis (Figure 5) shows that the spectra of the three membranes stripped by different strippers are almost identical. By comparing these spectra with the spectrum of the non-stripped membrane, it can be noted the quasi-total disappearance of the peak at $16.8^{\circ}$, which is probably due to crystalline impurity, confirming the degradation of the fouling layer by the various used strippers.

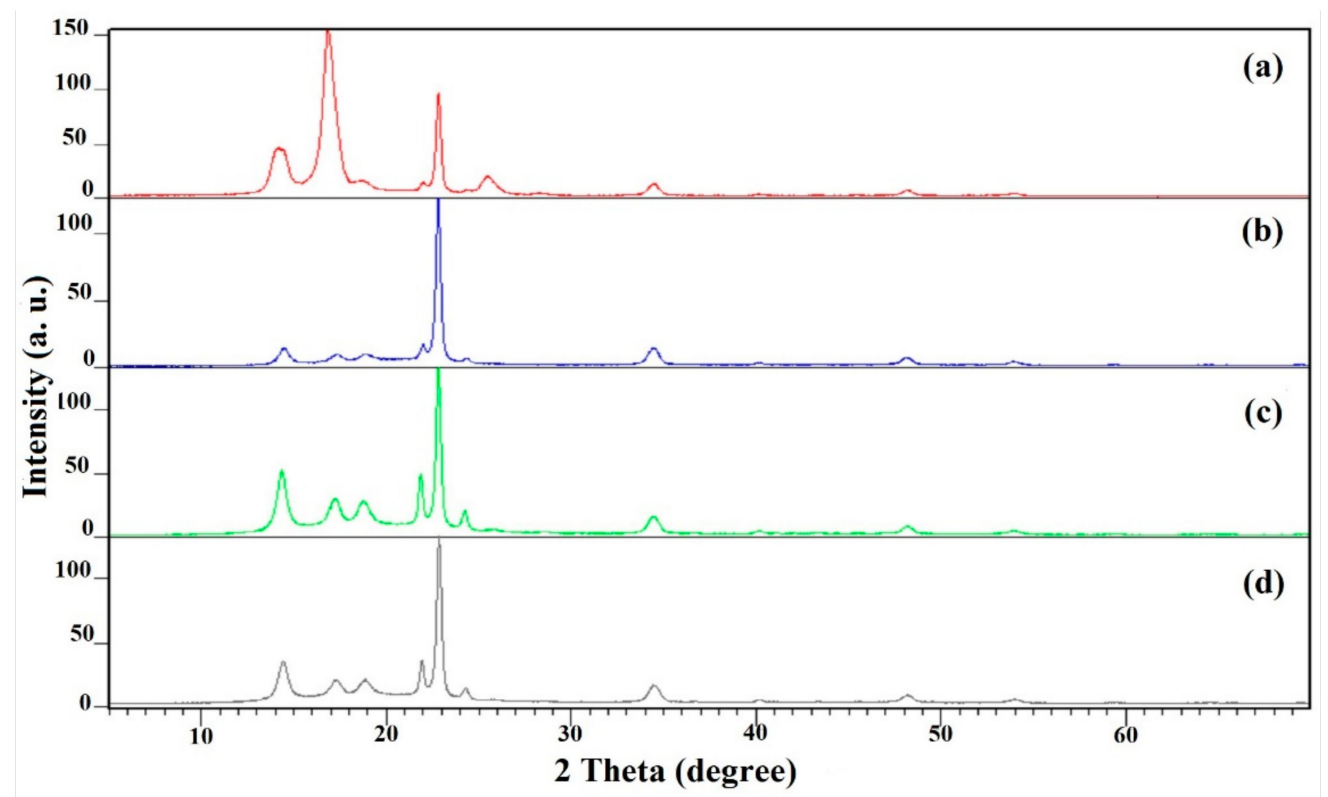

Figure 5. XRD diffractograms of the stripped and non-stripped membranes. (a) ESPA non-stripped, (b) $\mathrm{ESPA}+\mathrm{NaOH}$, (c) $\mathrm{KMnO}_{4}$ and (d) $\mathrm{ESPA}+\mathrm{KMnO}_{4} / \mathrm{NaOH}$.

\subsubsection{Hydraulic Permeability}

Table 3 shows the hydraulic permeability of the spent membrane and regenerated membranes using $\mathrm{NaOH}, \mathrm{KMnO}_{4}$ and $\mathrm{KMnO}_{4} / \mathrm{NaOH}$. It can be revealed from the table that stripping using $\mathrm{NaOH}$ increases approximately 40 times the hydraulic permeability of the spent membrane. In the case of $\mathrm{KMnO}_{4}$, there was a large increase in the hydraulic permeability, which could reach 45 times compared to the initial value. This can be mainly attributed to the composition of the solid deposits on the membrane and removal of active layer. More importantly, the results show that the hydraulic permeability did not increase during the next 7 days for all regenerated membranes. This indicates that the regenerated membranes were chemically stable.

Table 3. Permeability of spent and regenerated membranes.

\begin{tabular}{ccc}
\hline Membrane & $\mathbf{L}_{\mathbf{p}}\left(\mathbf{L ~ h ~ h ~}^{-\mathbf{1}} \mathbf{~ m}^{-\mathbf{2}} \mathbf{b a r}^{-\mathbf{1}}\right)$ & $\begin{array}{c}\mathbf{L}_{\mathbf{p}}\left(\mathbf{L ~ h}^{-\mathbf{1}} \mathbf{~ m}^{-\mathbf{2}} \mathbf{b a r}^{-\mathbf{1}}\right) \\
\mathbf{7} \mathbf{~ D a y s}\end{array}$ \\
\hline Spent membrane & $>1$ & $>1$ \\
Regenerated membrane using $\mathrm{NaOH}$ & 40 & 40 \\
Regenerated membrane using $\mathrm{KMnO}_{4}$ & 45 & 47 \\
Regenerated membrane using $\mathrm{KMnO}_{4} / \mathrm{NaOH}$ & 43 & 43 \\
\hline
\end{tabular}

\subsection{Clarification of Wet Process Phosphoric Acid}

\subsubsection{Flux}

Table 4 shows that WPPA $\left(29 \% \mathrm{P}_{2} \mathrm{O}_{5}\right)$ flux of regenerated membrane using $\mathrm{NaOH}$ is considerably lower than those regenerated using $\mathrm{KMnO}_{4}$ and $\mathrm{KMnO}_{4} / \mathrm{NaOH}$ under the same operating conditions. The difference in acid flux shows that the dominant cutoff effect. 
Table 4. WPPA flux of regenerated membranes.

\begin{tabular}{ccc}
\hline Membrane & $\begin{array}{c}\mathbf{J}_{\mathbf{p}}\left(\mathbf{L} \mathbf{~ h}^{-\mathbf{1}} \mathbf{~ m}^{-\mathbf{2}}\right) \\
\mathbf{1} \text { Day }\end{array}$ & $\begin{array}{c}\mathbf{J}_{\mathbf{p}}\left(\mathbf{L ~ h ~ h ~}^{-\mathbf{1}} \mathbf{~ m}^{-\mathbf{2}}\right) \\
\mathbf{7} \text { Days }\end{array}$ \\
\hline $\mathrm{ESPA}+\mathrm{NaOH}$ & 43 & 44 \\
$\mathrm{ESPA}+\mathrm{KMnO}_{4}$ & 54 & 56 \\
$\mathrm{ESPA}+\mathrm{KMnO}_{4} / \mathrm{NaOH}$ & 51 & 51 \\
\hline
\end{tabular}

\subsubsection{Rejection of Suspended Particles}

It was observed that the rejection of suspended particles using regenerated membrane treated with $\mathrm{NaOH}$ was considerably better than using it regenerated under $\mathrm{KMnO}_{4}$ treatment for identical operating conditions (Table 5). The difference in rejection rates confirms that the pore size of the membrane controls the rejection.

Table 5. Suspended particles rejection of regenerated membranes.

\begin{tabular}{ccc}
\hline Membrane & $\begin{array}{c}\text { Rejection (\%) } \\
\text { 1 Day }\end{array}$ & $\begin{array}{c}\text { Rejection (\%) } \\
\text { 7 Days }\end{array}$ \\
\hline $\mathrm{ESPA}+\mathrm{NaOH}$ & 70 & 69 \\
$\mathrm{ESPA}+\mathrm{KMnO}_{4}$ & 54 & 56 \\
$\mathrm{ESPA}+\mathrm{KMnO}_{4} / \mathrm{NaOH}$ & 65 & 65 \\
\hline
\end{tabular}

\subsubsection{Rejection of Organic Matter}

It was also observed that the organic matter rejection using the membrane regenerated with $\mathrm{NaOH}$ was close to that the membrane regenerated using $\mathrm{KMnO}_{4}$ for identical operating conditions (Table 6).

Table 6. Rejection of organic matter using regenerated membranes.

\begin{tabular}{ccc}
\hline Membrane & $\begin{array}{c}\text { Rejection (\%) } \\
\text { 1 Day }\end{array}$ & $\begin{array}{c}\text { Rejection (\%) } \\
\text { 7 Days }\end{array}$ \\
\hline $\mathrm{ESPA}+\mathrm{NaOH}$ & 61 & 54 \\
$\mathrm{ESPA}+\mathrm{KMnO}_{4}$ & 61 & 53 \\
$\mathrm{ESPA}+\mathrm{KMnO}_{4} / \mathrm{NaOH}$ & 59 & 59 \\
\hline
\end{tabular}

\section{Conclusions}

The purpose of this study was to examine: (i) Regeneration of membranes by chemical stripping of the active layer and fouling layer of spent ESPA RO membranes, and (ii) the application of the regenerated membranes for the treatment of industrial phosphoric acid, particularly for the rejection of suspended particles and organic matter.

The autopsy of the spent RO membrane showed the presence of external and internal clogging deposition of silicates in the form of clay. The experimental results showed that spent $\mathrm{RO}$ membrane was effectively transformed to $\mathrm{MF}$ membrane using $\mathrm{NaOH}, \mathrm{KMnO}_{4}$, and $\mathrm{KMnO}_{4} / \mathrm{NaOH}$ strippers. Furthermore, the regenerated membranes made it possible to achieve a rejection of $70 \%$ of the suspended materials and $61 \%$ of the organic matter. These results clearly show the potential of adopted process with these materials and could pave the way for the application of recycled spent RO membranes in the treatment and clarification of phosphoric acid expanding therefore the applicability of this technology in the phosphate industry. Finally, findings of the current study might contribute to solve the environmental [23-25] and economic issues generated by spent $\mathrm{RO}$ membranes adopting chemical conversion to be recycled as membranes for industrial clarification applications of under harsh conditions. 
Author Contributions: Conceptualization, K.K. and R.B. (Rachid Benhida); Formal analysis, K.K.; Funding acquisition, R.B. (Rachid Boulif) and R.B. (Rachid Benhida); Investigation, K.K. and B.A.; Software, R.B. (Rachid Boulif); Supervision, R.B. (Rachid Benhida); Validation, B.A.; Writing—original draft, K.K., B.A., R.B. (Rachid Boulif) and R.B. (Rachid Benhida); Writing-review \& editing, K.K., B.A. and R.B. (Rachid Benhida). All authors have read and agreed to the published version of the manuscript.

Funding: This research received no external funding.

Data Availability Statement: Not applicable.

Acknowledgments: We are grateful to UM6P and OCP for their supports.

Conflicts of Interest: The authors declare no conflict of interest.

\section{References}

1. Kim, J.; Park, K.; Hong, S. Application of Two-Stage Reverse Osmosis System for Desalination of High-Salinity and HighTemperature Seawater with Improved Stability and Performance. Desalination 2020, 492, 114645. [CrossRef]

2. Landaburu-Aguirre, J.; García-Pacheco, R.; Molina, S.; Rodríguez-Sáez, L.; Rabadán, J.; García-Calvo, E. Fouling Prevention, Preparing for Re-Use and Membrane Recycling. Towards Circular Economy in RO Desalination. Desalination 2016, 393, 16-30. [CrossRef]

3. de Paula, E.C.; Santos Amaral, M.C. Environmental and Economic Evaluation of End-of-Life Reverse Osmosis Membranes Recycling by Means of Chemical Conversion. J. Clean. Prod. 2018, 194, 85-93. [CrossRef]

4. Coutinho de Paula, E.; Amaral, M.C.S. Extending the Life-Cycle of Reverse Osmosis Membranes: A Review. Waste Manag. Res. J. Sustain. Circ. Econ. 2017, 35, 456-470. [CrossRef] [PubMed]

5. García-Pacheco, R.; Landaburu-Aguirre, J.; Molina, S.; Rodríguez-Sáez, L.; Teli, S.B.; García-Calvo, E. Transformation of Endof-Life RO Membranes into NF and UF Membranes: Evaluation of Membrane Performance. J. Membr. Sci. 2015, 495, 305-315. [CrossRef]

6. García-Pacheco, R.; Landaburu-Aguirre, J.; Terrero-Rodríguez, P.; Campos, E.; Molina-Serrano, F.; Rabadán, J.; Zarzo, D.; García-Calvo, E. Validation of Recycled Membranes for Treating Brackish Water at Pilot Scale. Desalination 2018, 433, 199-208. [CrossRef]

7. Pontié, M.; Awad, S.; Tazerout, M.; Chaouachi, O.; Chaouachi, B. Recycling and Energy Recovery Solutions of End-of-Life Reverse Osmosis (RO) Membrane Materials: A Sustainable Approach. Desalination 2017, 423, 30-40. [CrossRef]

8. Molina, S.; Landaburu-Aguirre, J.; Rodríguez-Sáez, L.; García-Pacheco, R.; de la Campa, J.G.; García-Calvo, E. Effect of Sodium Hypochlorite Exposure on Polysulfone Recycled UF Membranes and Their Surface Characterization. Polym. Degrad. Stab. 2018, 150, 46-56. [CrossRef]

9. Matta, S.; Stephan, K.; Stephan, J.; Lteif, R.; Goutaudier, C.; Saab, J. Phosphoric Acid Production by Attacking Phosphate Rock with Recycled Hexafluosilicic Acid. Int. J. Miner. Process. 2017, 161, 21-27. [CrossRef]

10. Trabelsi, W.; Tlili, A. Phosphoric Acid Purification through Different Raw and Activated Clay Materials (Southern Tunisia). J. Afr. Earth Sci. 2017, 129, 647-658. [CrossRef]

11. Abdel-Ghafar, H.M.; Abdel-Aal, E.A.; Ibrahim, M.A.M.; El-Shall, H.; Ismail, A.K. Purification of High Iron Wet-Process Phosphoric Acid via Oxalate Precipitation Method. Hydrometallurgy 2019, 184, 1-8. [CrossRef]

12. Paltrinieri, L.; Remmen, K.; Müller, B.; Chu, L.; Köser, J.; Wintgens, T.; Wessling, M.; de Smet, L.C.P.M.; Sudhölter, E.J.R. Improved Phosphoric Acid Recovery from Sewage Sludge Ash Using Layer-by-Layer Modified Membranes. J. Membr. Sci. 2019, 587, 117162. [CrossRef]

13. Li, H.; Ge, W.; Zhang, J.; Kasomo, R.M.; Leng, J.; Weng, X.; Chen, Q.; Gao, Q.; Song, S.; Xiao, L.; et al. Control Foaming Performance of Phosphate Rocks Used for Wet-Process of Phosphoric Acid Production by Phosphoric Acid. Hydrometallurgy 2020, 195, 105364. [CrossRef]

14. Gzara, L.; Hafiane, A.; Dhahbi, M. Rétention Des Ions Plomb (II) En Milieu Acide Par Ultrafiltration Assistée Par Les Micelles. Rev. Sci. Eau 2005, 13, 289-304. [CrossRef]

15. Monser, L.; Ben Amor, M.; Ksibi, M. Purification of Wet Phosphoric Acid Using Modified Activated Carbon. Chem. Eng. Process. Process Intensif. 1999, 38, 267-271. [CrossRef]

16. Moradi, M.R.; Pihlajamäki, A.; Hesampour, M.; Ahlgren, J.; Mänttäri, M. End-of-Life RO Membranes Recycling: Reuse as NF Membranes by Polyelectrolyte Layer-by-Layer Deposition. J. Membr. Sci. 2019, 584, 300-308. [CrossRef]

17. Liu, Q.; Wu, X.; Zhang, K. Polysulfone/Polyamide-SiO2 Composite Membrane with High Permeance for Organic Solvent Nanofiltration. Membranes 2018, 8, 89. [CrossRef] [PubMed]

18. Kumar, R.V.; Goswami, L.; Pakshirajan, K.; Pugazhenthi, G. Dairy Wastewater Treatment Using a Novel Low Cost Tubular Ceramic Membrane and Membrane Fouling Mechanism Using Pore Blocking Models. J. Water Process. Eng. 2016, 13, 168-175. [CrossRef]

19. Biswas, S.; Pathak, P.; Roy, S. Carrier Facilitated Transport of Uranium across Supported Liquid Membrane Using Dinonyl Phenyl Phosphoric Acid and Its Mixture with Neutral Donors. Desalination 2012, 290, 74-82. [CrossRef] 
20. Zondervan, E.; Zwijnenburg, A.; Roffel, B. Statistical Analysis of Data from Accelerated Ageing Tests of PES UF Membranes. J. Membr. Sci. 2007, 300, 111-116. [CrossRef]

21. Vegas, I.; Ibañez, J.A.; Lisbona, A.; Sáez de Cortazar, A.; Frías, M. Pre-Normative Research on the Use of Mixed Recycled Aggregates in Unbound Road Sections. Constr. Build. Mater. 2011, 25, 2674-2682. [CrossRef]

22. Mouratib, R.; Achiou, B.; Krati, M.E.; Younssi, S.A.; Tahiri, S. Low-Cost Ceramic Membrane Made from Alumina- and Silica-Rich Water Treatment Sludge and Its Application to Wastewater Filtration. J. Eur. Ceram. Soc. 2020, 40, 5942-5950. [CrossRef]

23. Eljamal, O.; Shubair, T.; Tahara, A.; Sugihara, Y.; Matsunaga, N. Iron Based Nanoparticles-Zeolite Composites for the Removal of Cesium from Aqueous Solutions. J. Mol. Liq. 2019, 277, 613-623. [CrossRef]

24. Ziolkowska, J.R. Is Desalination Affordable?-Regional Cost and Price Analysis. Water Resour. Manag. 2014, $29,1385-1397$. [CrossRef]

25. Shubair, T.; Eljamal, O.; Tahara, A.; Sugihara, Y.; Matsunaga, N. Preparation of New Magnetic Zeolite Nanocomposites for Removal of Strontium from Polluted Waters. J. Mol. Liq. 2019, 288, 111026. [CrossRef] 